3. Исаев А.А. Проведение занятий семинарского типа по социально-гуманитарным дисциплинам с использованием сервиса видеоконференцсвязи (на примере «Труконф») // Подготовка кадров для силовых структур: современные направления и образовательные технологии: материалы двадцать шестой Всероссийской научно-методической конференции. Иркутск, 2021. С. 232-234.

4. Исаев А.А. Роль деятельностного подхода в современном образовательном процессе // Вестник Уфимского юридического института МВД России. 2021. № 1 (91). С. 201-206.

5. Пенионжек Е.В. Особенности изучения политологии будущими юристами // Тенденции развития науки и образования. № 71, 2021. С. 132-136.

6. Соловьев А.И. Политология: политическая теория, политические технологии. М.: Аспект Пресс, $2001.559 \mathrm{c}$.

\title{
Полякова М.Д. \\ Использование ресурсов Интернета в дистанционном и очном обучении иностранному языку
}

\author{
МГОУ \\ (Россия, Москва)
}

doi: $10.18411 / / j-08-2021-48$

\section{Аннотация}

В статье поднимаются методические проблемы, с которыми сталкивается современный преподаватель английского языка, работая как в очном, так и в дистанционном формате. Делается акцент на развитие у студентов способности к самообразованию с помощью формирования стратегий обучения. В настоящее время, в эпоху цифровизации одной из актуальных задач самостоятельного обучения является развитие способности эффективной обработки поступающей информации. В связи с этим, даются рекомендации по работе с ресурсами Интернета, поиску и отбору материала, что имеет важное место на занятиях по английскому со студентами бакалавриата в вузе.

Ключевые слова: Интернет-технологии, Интернет-ресурсы, самоорганизация, самостоятельная деятельность, учебные стратегии, межкультурная коммуникация.

\section{Abstract}

The article rises the methodological problems that a modern English teacher faces when working both in full-time and in a distance format. The emphasis is on the development of students ' ability to self-education through the formation of learning strategies. Currently, in the era of digitalization, one of the actual goals of independent learning is the development of the ability to effecively process the incoming information. In this regard, the recommendations on dealing with Internet resources, search and selection of material, which play a key role for English classes in the bachelor's degree at the university, are given.

Keywords: Internet technologies, Internet resources, self-organization, independent activity, educational strategies, intercultural communication.

Последнее время мы наблюдаем быстрый рост Интернет-технологий и применение их в образовательном процессе, что заставляет преподавателей использовать новые формы и методы обучения. Хотя дистанционное и очное образование прочно вошли в нашу жизнь, остается множество нерешенных вопросов в области методики преподавания иностранных языков. Сегодня в наш словарь вошел термин blended learning - или смешанное обучение - образовательная концепция, в рамках которой студент получает знания и самостоятельно онлайн, и очно с преподавателем.

Качество обучения всегда зависит как от эффективной организации самого процесса обучения, так и от методической составляющей используемых материалов. Какой бы внешней привлекательностью не обладали технологии или используемые 
ресурсы, они сами по себе не приведут учебный процесс к желаемым результатам. В связи с этим, рассматриваются отношение к ресурсам Интернета, к информационным технологиям, поиску и отбору материала, - все это играет большую роль для эффективного преподавания иностранного языка.

Внешний эффект от ресурсов, которые находятся в сети Интернет, является причиной того, что педагогической и методической составляющей часто не уделяется внимание не только во время использования, но и на этапе проектирования учебных заданий. Поэтому важно уделять этим этапам должное значение.

Самоорганизация учебно-познавательной деятельности студентов сегодня стоит в центре внимания преподавателей. Согласимся с Т. Черниговской, что «задачи современного образования: тренировать понимание, а не запоминание, воспитание спокойного отношения к постоянным переменам, формирование навыков верификации информации, обучение способности учиться, противостоять стрессу и сохранять человечность в цифровом мире» [5].

Способность и потребность самостоятельно пополнять и обновлять теоретические и практические знания является в информационную эпоху общественно значимым требованием. Наше время характеризуется быстрым усвоением знаний, настоящей информационной и технологической революцией, затрагивающей все сферы жизни общества.

Когнитивный подход к обучению «основан на когнитивной психологии, опирающейся на принцип сознательности в преподавании и на теорию социо конструктивизма, согласно которой учащийся является активным участником процесса учения, а не объектом обучающей деятельности преподавателя» [1].

Поэтому, в зависимости от индивидуальных психологических особенностей и качеств личности, у обучаемых формируется определенный способ выполнения деятельности в процессе познания, путь познания мира, или когнитивный стиль. Исследователи выделяют разное количество когнитивных стилей, которые соотносятся с психологическими характеристиками типа личности и качествами человека. Применительно к изучению иностранных языков «основными когнитивными стилями можно считать следующие: полевая независимость (field independence), доминирующая роль одного из полушарий (left and right -brain functioning), толерантность (ambiguity tolerance), рефлексивность (reflectivity), импульсивность (impulsivity), визуальный и слуховой (visual and auditory)» [3].

Как правило, человек пользуется определенным набором когнитивных стилей, однако более успешной оказывается деятельность тех, кто умеет сознательно выбирать и эффективно использовать разные когнитивные стили. Задача преподавателя помочь учащимся понять свой когнитивный стиль, который и определяет его учебный стиль и влияет на выбор его учебных стратегий.

При обучении языку с учетом профессиональной ориентации важной составляющей процесса обучения является текст (это может быть профессиональная статья, пресс релиз, текст выступления и т.д.). Правильный выбор материала для чтения позволяет получить интересный профессиональный, мотивирующий текст для учащегося, активизировать современный лексико-грамматический запас, овладеть профессионально-ориентированными понятиями, использовать в коммуникативных целях, использовать для выработки навыков письменной речи (аннотации, реферата, эссе).

Аутентичные статьи используются со студентами бакалавриата 3 курса на занятиях по профессиональному английскому языку в рамках дополнительных заданий к основному курсу. Работа с ними является неотьемлемой частью курса, и как следствие студенты понимают, как использовать статьи из Интернет-ресурсов для самостоятельной работы над языком. Прорабатывая стратегии работы с аутентичным текстом в аудитории, студенты вырабатывают свое понимание работы, приемы, которые являются для них предпочтительными, ускорят процесс обучения, сделают его более легким, и в целом более эффективным. 
Актуальными являются упражнения к статье для аудиторной работы со студентами. Помимо профессиональных и коммуникативных компетенций, они призваны развить следующие навыки владения языком: а) понимание основной идеи текста; б) выделение основных фактов, отражающих логику развития информации; в) понимание деталей информации; г) установление причинно-следственных связей сообщаемого; д) понимание точки зрения автора; е) анализ информации и установление ее достоверности; ж) определение собственной позиции и оценка сообщаемой информации; з) оценка поставленной проблемы и предложение способов ее решения; и) умение вести дискуссию по предложенной проблеме.

На 3 курсе бакалавриата на занятиях по профессиональному иностранному языку ставится задача развития умений коммуникативного или зрелого чтения. Зрелое чтение подразумевает такой подход к письменному тексту, при котором читающий ясно представляет себе цель предстоящей деятельности. Оно характеризуется автоматизированностью техники чтения и высоким уровнем развития рецептивных лексико-грамматических навыков, что обеспечивает направленность внимания на содержание читаемого, гибкость комбинирования приемов, адекватных конкретной задаче. В отечественных методических публикациях за последние годы признание получили такие термины, как «чтение с выборочным извлечением информации», «чтение с пониманием основного содержания» и «чтение с полным пониманием текста» (И.М. Бим, М.В. Кузовлев, А.А. Миролюбов). Среди британских методистов употребляются термины, обозначающие коммуникативное чтение: scanning, skimming and reading for detailed comprehension.

Однозначно, преподаватель английского языка - это многогранная личность. Быть успешным преподавателем сегодня значит иметь обширные знания в разных областях, уметь ими пользоваться и применять на занятиях. Чем прогрессивнее становится общество, тем больше ролей включает преподавательский послужной список. Чтобы оставаться 'on top of the game', необходимо самому поддерживать на уровне языковые навыки, но и быть в курсе новых технологий, методик и интересных каналов.

Электронный учебник является удобным носителем большого объема информации. Учебник легко проецируется на доске и легко настраивается, учитывая особенность каждой группы. Эффективность подобного средства состоит в том, что информация, представленная в нем, легко изменяется.

Программа TEAMS Инструмент, доказавший свою эффективность во время пандемии, остается эффективным средством для проведения видео - конференций, конкурсов, консультаций. Помимо общения, студенты успешно тренируют письменную речь, комментируя происходящее в текстовом чате.

Использование компьютерных технологий, сети Интернет на занятиях по английскому языку упрощает работу преподавателя и студента. Сегодня трудно представить учебный процесс без компьютерных программ и сети Интернет. Они помогают преподавателям и учащимся самостоятельно повышать свой уровень, оценивать свои навыки и умения, дополнять аудиторный процесс, консультироваться, заявлять о себе на профессиональных международных форумах.

$$
* * *
$$

1. Азимов Э.Г., Щукин А.Н. Новый словарь методических терминов и понятий (теория и методика обучения иностранным языкам). - М.: Изд-во «Икар», 2009. - 605 с.

2. Большая психологическая энциклопедия [Электронный ресурс] - Режим доступа: http:// encyclopedia.ru/ (дата обращения: 14.04.2021).

3. Колесникова И.Л., Долгина О.А. Англо-русский терминологический справочник по методике преподавания иностранных языков. - CUP, Санкт-Петербург, 2001. - С. 58.

4. Пассов Е.И., Кузовлева Н.Е. Основы коммуникативной теории и технологии иноязычного образования. - М., 2010. - С. 12.

5. Черниговская Т. Интернет, мозг и «жидкий мир». - М., 2016. - 219 с. 